\title{
AS MULHERES PROFESSORAS, AS MENINAS LEITORAS E O MENINO LEITOR: A INICIAÇÃO NO UNIVERSO DA ESCRITA NO PATRIARCALISMO RURAL BRASILEIRO. UMA LEITURA A PARTIR DE INFANCIA DE GRACILIANO RAMOS
}

\author{
Ana Lúcia Guedes-Pinto* \\ Roseli Aparecida Cação Fontana ${ }^{* *}$
}

\begin{abstract}
RESUMO: Propomo-nos, neste trabalho, a realizar, com base na obra Infância de Graciliano Ramos, uma análise da participação da mulher no processo de iniciação escritural das crianças, nas primeiras décadas do século XX, no nordeste brasileiro. A despeito do lugar ocupado pela mulher no patriarcalismo rural, sua presença mostra-se expressiva na multiplicidade de modelos de escolarização, seja na esfera pública ou na esfera doméstica, herdados do século XIX. Trabalhando nas interfaces entre a história cultural, a antropologia, a sociologia e os estudos da linguagem, pretendemos focalizar tanto os espaços e as práticas em que as crianças eram iniciadas na aprendizagem da leitura e da escrita por suas professoras, familiares e amigas quanto os significados de que se revestiam, para essas mulheres e crianças, as tarefas relativas ao ensino.
\end{abstract}

Palavras-chave: Leitura. Escrita. Letramento. Práticas escolares e nãoescolares.

* Professora da Faculdade de Educação da Universidade Estadual de Campinas (UniCAmp), coordenadora do grupo aUla e pesquisadora do Centro de Memória da UNICAMP (CMU). E-mail: alguedes@mpc.com.br

** Professora da Faculdade de Educação da Universidade Estadual de Campinas (UNICAMP) e pesquisadora do grupo AULA. E-mail: roap@uol.com.br

Disponível em <http://www.cedes.unicamp.br> 
As mulheres professoras, as meninas leitoras e o menino leitor...

WOMEN TEACHING AND GIRLS AND A BOY AS READERS: TEACHING WRITING AND READING IN THE PATRIARCHAL BRAZILIAN RURAl SOCIETy. A VIEW BaSED ON Graciliano Ramos' NOVEL

\section{INFÂNCIA}

ABSTRACT: Based on the novel Infância, by Graciliano Ramos, we analyse the role of women in the process of teaching children to write and read during the first decades of the $20^{\text {th }}$ Century, in Northeastern Brazil. Despite their secondary position in the patriarchal Brazilian rural society, the presence of women is expressive in the numerous educational models inherited from the $19^{\text {th }}$ Century, be they in the public or domestic sphere. Working at the interfaces between cultural history, anthropology, sociology, and linguistics, we focus both the practices and the locus these teachers, relatives, and friends adopted in the process of teaching children to write and read. We also analyse the meaning content of the educational tasks involving these women and children.

Key words: Reading. Writing. Literacy. Formal and informal education practices.

\section{Apresentação}

omo professoras que fomos, da escola de ensino fundamental, e como professoras hoje envolvidas com a formação inicial de professores no curso de pedagogia, interessou-nos, sempre, ao longo de nossa constituição como profissionais, a compreensão das práticas escolares e docentes, em sua condição de práticas históricas. E, ao optarmos por compreendê-las a partir desta perspectiva, sentimonos provocadas a estender nosso campo de investigação, procurando construir caminhos por entre práticas socioculturais que, embora não se caracterizem como pertencentes ao universo escolar, fazem parte de suas origens ou dele sempre estiveram próximas.

Trabalhando com a prática de ensino, um componente teóricoprático da formação docente, cuja compreensão abarca as discussões teórico-metodológicas relativas ao ensino, mas nelas não se esgota, temos buscado articular o questionamento feito no âmbito dos textos pedagógicos com os estudos da linguagem, da história cultural e também da antropologia.

As interlocuções com os estudos dessas áreas têm nos possibilitado construir categorias analíticas e princípios explicativos para a 
compreensão do pedagógico em sua complexidade e multideterminação. A literatura, por sua vez, tem nos aproximado da singularidade da experiência humana. Isto é, justamente por não pertencer ao campo científico, permite-nos mergulhar em mundos alheios, em que personagens vivem seus enredos ou suas tramas despreocupadas de regras ou teorias explicativas generalistas, por exemplo. Porém, tais enredos ou tramas, bem como os modos de dizer em que se materializam, não se desenvolvem livres e soltos do curso da história do homem. E é neste âmbito que sentimos que a literatura nos favorece uma aproximação da experiência. Conforme Lajolo (2001, p. 47) afirma:

O mundo representado na literatura - por mais simbólico que seja - nasce da experiência que o escritor tem de sua realidade histórica e social. (...) embora comprometida com o mundo do possível e não com o mundo real, a criação literária nasce de uma imaginação ancorada na realidade.

Assim, a literatura tem nos possibilitado alternativas de percursos para o estudo das práticas escolares e não-escolares, destacandose, entre elas, aquelas relativas à iniciação e inserção dos sujeitos às normativas do mundo da escrita. Mundo esse que marca profundamente os processos formais de educação, tanto porque a escola esteve sempre intimamente ligada à tarefa de ensinar a ler e a escrever quanto porque, nessa instituição, a escrita é privilegiada, com relação a outras formas de linguagem, nos processos de apropriação, elaboração e consolidação dos conhecimentos escolares.

No curso de nossas indagações e leituras sobre o ensino e o uso da escrita, as questôes relativas à feminização do magistério (a partir do século XX), como um modo feminino de ocupar (ou viver) as relações na escola, foram se impondo. Nossa curiosidade voltou-se para o desenvolvimento do processo de inserção social e profissional da mulher nesse espaço marcado pela escrita, ao considerarmos a subordinação ao homem e a reclusão dos espaços públicos, em que as mulheres foram mantidas pelo regime patriarcal agrário, bem como a parca circulação das práticas de leitura e escrita nessa formação social.

Como no espaço das últimas cinco décadas do século XIX, período de criação das primeiras escolas normais provinciais, destinadas apenas aos rapazes, a emergente, e quase exclusivamente masculina, profissão docente tornou-se predominantemente feminina? (Villela, 2000, p. 119). 
As mulheres professoras, as meninas leitoras e o menino leitor...

Os estudos da história confirmam que, durante todo o período colonial, imperial e mesmo no início do período republicano, a educação feminina, assentada em uma grande distância social, extrema especialização e diferenciação entre os sexos, ficou restrita aos cuidados com a casa, com o marido e com os filhos. Raros foram os casos, nesse período, de mulheres letradas e daquelas que ultrapassaram a esfera doméstica, assumindo uma atuação administrativa (Freyre, 1936; Ribeiro, 2000).

No jogo de reciprocidade que se tecia entre as opostas condiçôes feminina e masculina, sob a égide do patriarcalismo rural, gerações de meninos e meninas aprenderam a apresentar-se como homens e como mulheres, elaborando em si os modos de dizer, os modos de comportar-se, os modos de apresentarem seus próprios corpos e de significarem a si mesmos, a suas emoçóes e a seus gostos, mediados pela linguagem verbal e não-verbal em circulação em seus grupos sociais.

"Em se tratando da educação para o sexo feminino, o ideal era a preparação para a permanência no espaço privado" (Ribeiro, 1996, p. 44). As oportunidades de convívio social das mulheres, de acordo com Freyre (1936), eram limitadas aos filhos, às amas, à parentela, às velhas e aos escravos, e vez por outra ao contato com o confessor. Recolhidas ao interior das casas-grandes, onde eram educadas, as mulheres participavam de práticas linguageiras específicas de uma parcela restrita do universo social da época. Longe do domínio econômico e político exercido pelos homens, as mulheres sabiam da administração da casa, das costuras, do ponto dos doces, das rezas. As relaçôes interlocutivas de que participavam, centradas nesse universo doméstico, ensinavam-lhes, também, a pouco falar, a serem regradas e submissas.

Conforme Ribeiro (2000, p. 79), "tanto as mulheres brancas, ricas ou empobrecidas, como as negras escravas e as indígenas não tinham acesso à arte de ler e escrever". O acesso à leitura, que algumas chegavam a ter, era garantido pelo aprendizado na família, durante a infância e destinado aos livros de reza. "O acesso aos livros de literatura era limitado e não passava, muitas vezes, do livro de orações, que servia também de iniciador das mulheres na página impressa" (Morais, 1998, p. 74).

A única alternativa que restava àquelas que quisessem estudar era o ingresso nos conventos, onde o ensino da leitura e da escrita era 
ministrado ao lado da música, do cantochão, do órgão e dos trabalhos domésticos - principalmente o preparo de doces e de flores artificiais (Ribeiro, 1996, p. 86-87).

No século XIX, uma série de mudanças teve lugar na sociedade brasileira. Embora essas mudanças culturais não tenham atingido de imediato a educação das mulheres que, em 1815, segundo observações registradas por Jean Baptiste Debret, ainda se limitavam "a recitar preces de cor e a calcular de memória sem saber escrever ou fazer as operações" (Ribeiro, op. cit., p. 90), elas produziram alterações significativas para que se possa entender a feminização do magistério a partir do século XX.

Se a história nos dá conta das grandes linhas do processo de declínio do patriarcalismo rural e do desenvolvimento das cidades, foi na literatura que nos aproximamos do cotidiano das práticas que se produziram nesse período e dos modos como foram experimentadas e significadas pelas gentes que as viveram.

Percorrendo com Graciliano Ramos (1945) as lembranças de sua infância, vivida no interior de Pernambuco e Alagoas, entre 1892 (ano de seu nascimento) e 1905 (ano em que o autor ingressa, aos 13 anos, no regime de internato, no Colégio do prof. Agnelo, em Maceió), deparamo-nos, surpresas, com a expressiva presença feminina nos processos de aprendizado da escrita pelo menino.

As mulheres participaram de seus contatos iniciais com a escrita e com a leitura, tanto como leitoras mais velhas ou como companheiras da mesma idade, no âmbito das relações familiares - tais como sua mãe, Mocinha, Emília -, quanto como professoras inseridas na educação escolar formal - como D. Maria, D. Maria do Ó e D. Agnelina ou como colegas nas relaçóes escolares - como Laura. Nesses distintos papéis sociais, essas mulheres mediatizaram a apropriação da escrita por Graciliano e os sentidos que ele foi elaborando dessa prática, em uma sociedade que, por séculos, alijou-as desse saber.

O tempo - final do século XIX e início do século XX -, o lugar - Pernambuco e Alagoas, províncias influentes, mas não dominantes na política nacional desse período -, a riqueza de detalhes e a intensidade com que o autor relata os modos de comportar-se, as práticas e as sensibilidades vividas mostraram-se decisivos em nossa escolha pelo texto Infância e em nossa opção por trabalhar na interlo- 
As mulheres professoras, as meninas leitoras e o menino leitor...

cução entre a literatura, a história e a antropologia, como possibilidade de compreensão do passado que engendra nosso presente.

Ao optarmos pelo texto literário para alicerçarmos nosso trabalho, pedimos licença ao campo teórico específico das letras e artes, por focalizá-lo como fonte de indícios de processos já ocorridos e sobre ele lançarmos esforços de análise e discussão. Alertamos também ao campo da história, reconhecendo, com Le Goff (1984, p. 180) apud Vidal (1990), que "tal como o passado não é a história, mas seu objeto, a memória não é a história mas um de seus objetos e simultaneamente um nível elementar de elaboração histórica”.

Desenvolveremos nossa análise em quatro partes. Na primeira consideramos as mediações da mãe e da irmã no aprendizado da leitura pelo menino, os significados dessas práticas no seio do grupo social a que pertenciam e os sentidos por eles atribuídos ao ato de ler. $\mathrm{Na}$ segunda parte, focalizamos o ingresso de Graciliano na escola, caracterizando que escola era essa. Em seguida apresentamos as três mulheres professoras a quem ele se reporta. Finalmente na quarta parte aproximamo-nos das mediações das meninas leitoras.

\section{O aprendizado doméstico da leitura e da escrita - as mediaçóes} da mãe e da irmã

Filho de comerciante e neto de donos de fazenda, o menino Graciliano viveu sua infância no interior de Pernambuco e de Alagoas. Buíque e Viçosa, duas pequenas vilas, são os cenários de suas lembranças nada saudosas, divididas entre pessoas, sentimentos e ressentimentos experimentados nas relações dentro da família patriarcal e na escola de métodos rígidos.

Em Buíque viveu dos dois aos oito anos. Ali, aprendeu com o pai as cinco primeiras letras do alfabeto, entre lágrimas, soluços, palmas vermelhas, mãos inchadas que latejavam como se funcionassem relógios dentro delas. ${ }^{1}$

O pai dispusera-se a ensinar-lhe as letras ao perceber sua atenção com relação às cartas de alfabetização que ele vendia em sua loja.

Demorei a atenção nuns cadernos de capa enfeitada por três faixas verticais, borrôes, nódoas cobertas de riscos semelhantes aos dos jornais e dos li- 
vros. Tive a infeliz idéia de abrir um desses folhetos, percorri as páginas amarelas, de papel ordinário. Meu pai tentou avivar-me a curiosidade valorizando com energia as linhas mal impressas, falhadas, antipáticas. Afirmou que as pessoas familiarizadas com elas dispunham de armas terriveis. (...) Ai meu pai perguntou se eu não desejava inteirar-me daquelas maravilhas, tornar-me um sujeito sabido como Padre João Inácio e o advogado Bento Américo (...).

Recorrendo a dois modelos de homens socialmente bem-sucedidos - o padre e o bacharel -, o pai tenta alfabetizar o menino em casa. Essa prática comum era uma herança do período colonial, quando a educação estivera restrita à esfera privada, dependendo da importância e do sentido que as famílias conferiam à aquisição da cultura letrada. Assim, durante todo o período colonial, nas grandes propriedades rurais, padres ligados aos engenhos ensinavam filhos de fazendeiros, agregados e até escravos. Posteriormente, enquanto o modelo escolar moderno não foi internalizado, essa forma de instrução passou a ser retransmitida em âmbito doméstico por aqueles que dominassem alguma habilidade de leitura, escrita, cálculo etc. (Villela, 2000, p. 97-99).

O pai do menino, ainda que imbuído da importância social da escrita entre os homens, desiste do projeto de ensino a que se propusera.

Meu pai não tinha vocação para o ensino, mas quis meter-me o alfabeto na cabeça. Resisti, ele teimou - e o resultado foi um desastre. Cedo revelou impaciência e assustou-me. Atirava rápido meia dúzia de letras (...) à tarde pegava um côvado, levava-me para a sala de visitas - e a lição era tempestuosa.

Quando o pai desistiu de tentar ensinar-lhe, transferiu a tarefa docente a Mocinha, sua irmã natural. Apesar da brevidade da experiência, o método adotado, a impaciência demonstrada, os comentários e os gestos de rigor desmesurados marcaram as primeiras concepções do menino acerca da escrita e de si mesmo: Afinal meu pai desesperou de instruir-me, revelou tristeza por haver gerado um maluco e deixou-me. Respirei, meti-me na soletração, guiado por Mocinha.

Mocinha é a primeira mulher a aparecer, no relato, como mediadora do aprendizado das primeiras letras pelo menino. Ela não era a professora no sentido profissional da palavra, mas não demonstra, na narrativa, nenhum constrangimento em guiar o irmão na explora- 
As mulheres professoras, as meninas leitoras e o menino leitor...

ção das cartas. Sua relação com o menino é branda e assenta-se na confiança em sua proteção, gesto apreendido ainda sob os exercícios paternos, quando a mãe e a irmã tentavam livrá-lo dos excessos do pai. Minha mãe e minha irmã natural me protegeram: arredaram-me da loja e, na prensa do copiar, forneceram-me as noçôes indispensáveis.

Essa atitude de proteção das mulheres com relação às crianças é destacada por Gilberto Freyre (1936, p. 138). Segundo ele, a mãe, no patriarcalismo, "era a aliada do menino contra o pai excessivo na disciplina e às vezes terrivelmente duro na autoridade”. Era sua consoladora e sua enfermeira, fazia-lhe, por vezes, as vontades, repercutindo de forma sentimental sobre ele, mais do que como colaboradora psicológica, interessada no seu desenvolvimento pessoal. Conforme as palavras de Freyre, "a influência de mulher que faltou sobre o filho menino ou adolescente foi a da mãe que compreendesse o mundo para o qual ele caminhava às cegas e sem um esclarecimento" (op. cit., p. 139).

Mocinha, a exemplo da mãe do menino e das vizinhas que freqüentavam a casa, não tinha um grande domínio da leitura. Minha mãe, descreve Graciliano,

lia devagar, numa toada inexpressiva, fazendo pausas absurdas, engolindo vírgulas e pontos, abolindo esdruxxulas, alongando ou encurtando palavras. Não compreendia bem o sentido delas. E, com tal prosódia e tal pontuação, os textos mais simples se obscureciam.

Apesar da quase soletração, essas mulheres se entregavam à leitura de romances, achando intençôes picarescas nas gravuras soltas, onde a tinta esmorecia, sob nódoas, aos almanaques ${ }^{2}$ e a publicações religiosas de milagres ingênuos, parábolas, biografias de santos, lendas, conselhos exigentes, delícias vagas do céu e torturas minuciosas do inferno, que tanto as enlevavam quanto apavoravam.

Entre a excitação, o êxtase e o medo, a leitura, consentida em sua reconhecida inutilidade fora do artigo politico e dos lançamentos do borrador, moldava tanto a obediência quanto os arroubos contestadores das mulheres.

No episódio "O fim do mundo", Graciliano relata o pavor que a mãe sentiu quando soube, lendo, provavelmente os almanaques, que o mundo estava no fim. ${ }^{3}$ Seguindo a mãe, que desesperava em silên- 
cio, o menino, sentindo o coração pesado, um bolo na garganta, desejou aliviá-la, dizer qualquer coisa oportuna. Apiedado dela, sentia que as desavenças entre ambos morriam. A relação entre mãe e filho é mostrada com beleza nessa passagem, em que, em contraponto, figuram o desespero da mulher adulta que não ousa discutir a veracidade das profecias e a criança que resiste e recusa o vaticínio. Enquanto a mãe o agarra e abraça violentamente, chorando, o menino pede explicaçôes, pondera, desacredita, julgando-a fraca e boa.

Já ao relatar a trajetória de Mocinha, Graciliano dá-nos indícios da resistência feminina às normas do patriarca. Mediada pela mesma prática da leitura que submetia a mãe, Mocinha tece um outro destino para si.

Mocinha bordava palmas e flores, engomava saias, ouvia missas. No romance extenso e amarfanhado travara conhecimento com $D$. Rufo e Adélia. E transformava Miguel num virtuoso galā. O nosso governo totalitário admitia Adélia e D. Rufo, mas não admitia Miguel. Não tentava suprimir a ficção contida nos volumes sujos. Consentia a leitura, reconhecendo a inutilidade dela fora do artigo político e dos lançamentos do borrador. Mas, deixando à menina o direito de pensar em tipos de histórias, decidiu conservá-la na virgindade. (...) Continuaria a sustentar Mocinha, conquanto ela procedesse direito, vivesse calma, na gaiola e na moral.

Contudo, a solidão a afligia. E Miguel não queria ser figura de romance. Entenderam-se, apesar da proibição, inflamaram-se, cambiaram acenos e bilhetes. E tudo se resolveu. Mocinha então fugiu.

Essas mulheres leitoras de romances saboreavam, por intermédio da leitura dos poucos livros que lhes chegavam às mãos ou dos materiais impressos aos quais tinham acesso, um outro mundo. Segundo Perrot (1998, p. 32), pesquisadora da história das mulheres,

as mulheres são, no século XIX, grandes leitoras de romances ricos em figuras femininas de toda espécie. A leitura, prazer tolerado ou furtivo, foi para muitas mulheres um jeito de se apropriar do mundo, do universo exótico das viagens e do universo erótico dos coraçóes.

Essa realidade de se ter mais espaços conquistados no âmbito privado da vida da mulher e de intercâmbio maior entre a esfera pública e a privada tem relação com as mudanças produzidas na socie- 
As mulheres professoras, as meninas leitoras e o menino leitor...

dade brasileira, que culminaram no século XIX com o desenvolvimento das cidades e das indústrias em uma sociedade essencialmente rural. O século XIX marca, conforme destaca Freyre (1936), o declínio do patriarcado rural brasileiro.

A casa patriarcal - símbolo da acomodação do escravo ao senhor, do preto ao branco, do filho ao pai, da mulher ao marido perdeu, nas cidades e nos sítios, parte de seus sentidos originais. Segundo o autor, "os senhores dos sobrados e os negros libertos, ou fugidos, dos mucambos, foram se tornando extremos antagônicos" (1936, p. 14).

Quando a paisagem social começou a se alterar entre nós, no sentido das casas-grandes se urbanizarem em sobrados mais requintadamente europeus, com as senzalas reduzidas quase a quartos de criados, as moças namorando das janelas para a rua, as aldeias de mucambos, os "quadros", os cortiços crescendo ao lado dos sobrados, mas quase sem se comunicarem com eles, os xangôs se diferenciando mais da religião católica do que nos engenhos e nas fazendas, aquela acomodação quebrou-se e novas relações de subordinação, novas distâncias sociais começaram a se desenvolver entre o rico e o pobre, entre o branco e a gente de cor, entre a casa-grande e a casa pequena. Maiores antagonismos entre dominadores e dominados. Entre meninos criados em casa e moleques criados na rua. Entre a dona da casa e a mulher da rua. Entre as gentes dos sobrados e a gente dos mucambos. (1936, p. 14-15)

Essa redefinição das relações, passando por novas posturas tanto em termos das tensóes criadas entre os espaços públicos das ruas e da praça e o espaço privado da casa quanto no sentido de limitar os abusos do particular e da casa e de fixar a importância, a dignidade, os direitos da rua, outrora tão por baixo e tão violados, alcançou também as relações entre os sexos.

"Ao se distanciarem senhores e escravos, tão íntimos dentro do patriarcalismo integral e ao se aproximarem as casas nobres umas das outras e todas das igrejas, dos teatros e da rua", a paisagem social da mulher alargou-se (Freyre, 1936, p. 161). Nos sobrados das cidades, destaca o autor, a mulher passou a experimentar uma maior variedade de contatos com a vida extradoméstica, por meio do teatro, do romance, da janela, do estudo de dança, de música, de francês, ainda que a rua lhe continuasse interditada: "A dona de casa que saísse rua 
afora para fazer compras corria o risco de ser tomada por mulher pública" (idem, ibid., p. 16).

Nas pequenas vilas, essa paisagem também se alarga, em escala muito menor, mas o suficiente para possibilitar algum acesso das mulheres às leituras e a um convívio social mais intenso com as vizinhas. Perrot (1998, p. 48) também destaca essa pequena mudança: "O uso desses espaços minúsculos [a calçada em frente da casa, da janela, da varanda] e sua representação indicam a importância do umbral que, como uma fronteira, separa o público do privado".

A mulher "semipatriarcal" do sobrado, "menos servil e mais mundana, caracterizou-se, por um lado, por menos devoção religiosa, menos confessionário, menos história da carochinha contada pela negra velha, menos conversa com as mucamas" (Freyre, 1936, p. 135) e, por outro, por mais romance, maior contato com o médico de família, que foi se tornando mais poderoso que o confessor, e mais influenciada pelo teatro, que seduzia mais que a igreja.

Apesar de limitada ainda em sua mobilidade por entre os espaços designados na sociedade que se desenhava, as inovações no cenário urbano-rural abriam possibilidades à mulher. Ela passou a ter contatos um pouco mais diversificados, favorecendo assim, nas brechas possíveis, o desenvolvimento de certa astúcia no aproveitamento das ocasióes. Perrot (1998, p. 64) ressalta essa abertura relativa conquistada pelas mulheres, de se fazer uso de determinadas situações, principalmente aquelas que favoreciam ambigüidades e que lhes poderiam fornecer alguns frutos: "A conversação, privada por seu exercício, eventualmente pública por seu conteúdo, é circulação e troca; ela embaralha fronteiras". Nessa ambiência, forja-se a resistência de Mocinha.

No entanto, as possibilidades de expressão e de intervenção das mulheres na vida extradoméstica continuaram insignificantes, reduzidas a formas graciosas e inócuas. Sua educação, embora tivesse incorporado algumas práticas não presentes na educação colonial, ainda as mantinha indolentes e incultas. Apegadas à casa e à família, pouco se interessavam pelos negócios e pela política e não compreendiam o mundo em que os homens agiam. "Ignorando que houvesse pátria, Império", pouco ou nada colaboravam nas atividades extradomésticas que compunham o universo do marido e dos filhos, exercendo sobre eles 
As mulheres professoras, as meninas leitoras e o menino leitor...

uma influência e repercussão, conforme destaca Freyre (1936, p. 135), puramente sentimental.

E é esse lado sentimental, de relações pessoais mais horizontalizadas e próximas, que se destaca nas relações de ensino tecidas entre Mocinha e o irmão. Sua relação mais amena e tranqüila facilitou-lhe o entendimento: Respirei, meti-me na soletração, guiado por Mocinha. E as duas letras amansaram.

Com Mocinha, o menino conseguia dirigir-lhe a palavra, manifestar inquietações. Na situação de aula informal em sua casa, com uma pessoa que parecia aceitá-lo na sua condição, o menino permitia certa exposição. O episódio da leitura das cartas de alfabetização, com a decifração de frases que continham teor moral e que para ele não faziam sentido, traz pistas dessa relação mais "aberta":

Eu não lia direito, mas, arfando penosamente, conseguia mastigar os conceitos sisudos: (...) "Fala pouco e bem: ter-te-ão por alguém." Esse Terteão para mim era um homem, e não pude saber que fazia ele na página final da carta. - Mocinha, quem éo Terteão? Mocinha estranhou a pergunta. Não havia pensado que Terteão fosse homem. Talvez fosse. "Fala pouco e bem: ter-teão por alguém." - Mocinha, que quer dizer isso? Mocinha confessou honestamente que não conhecia Terteão.

O menino e a mulher, muito mais próximos socialmente do que o pai e o filho, intercambiavam saberes e não-saberes. À fragilidade emotiva e intelectual das mulheres, não só cabia como era aceitável a ignorância. Nessa relação, iam-se elaborando no menino e em suas interlocutoras os lugares sociais ocupados pelo homem, o papel e a relevância da escrita para eles, bem como os lugares sociais das mulheres e o caráter de adereço de que a escrita se revestia na sua formação.

\section{Da casa para a escola - que escola?}

A notícia veio de supetão: iam meter-me na escola. (...) A escola, segundo informaçôes dignas de crédito, era um lugar para onde se enviavam as crianças rebeldes. (...) Considerei a resolução de meus pais uma injustiça.

Revestida de uma imagem aversiva, a escola apresentava-se, no imaginário infantil da época, como um espaço em que os adultos dis- 
ciplinavam as crianças fazendo uso de castigos, punições e escárnio, contra elas. Essa imagem tanto era uma herança dos métodos e das relações disciplinares produzidas pelos padres, que ensinavam nas casas-grandes e nos austeros colégios jesuíticos, quanto dos mestres régios, cujas práticas de ensino, assentadas no princípio de que "a letra com sangue entra”, faziam-se acompanhar das palmatórias.

Mas para que escola os pais do pequeno Graciliano tencionavam enviá-lo?

Em Buíque havia duas escolas assim descritas por Graciliano:

a escola pública, alva, de platibanda, regida por um sujeito de poucas falas e barba longa, semelhante ao mestre rural visto anos atrás. Essa parecença me deu a convicção de que todos os professores machos eram cabeludos e silenciosos.

Dona Maria, particular e casada com seu Antônio Justino, funcionava na rua da Palha -e, por ser particular, excedia o colega, oficial e, conseqüentemente, desleixado, na opinião dos pais de familia. Seu Antonio Justino, homem sem profissão, era quinca, marido de professora, mas não completamente quinca, apesar de viver desocupado. Se a mulher possuisse carta, seu Antonio Justino perderia nome e sobrenome. Dona Maria não tinha carta nem recebia dinheiro do governo - e seu Antonio Justino ainda não se havia inteiramente despersonalizado.

Nessa descrição, Graciliano sintetiza dois tipos de escola existentes no país a partir do século XIX: as escolas régias ou cadeiras públicas de primeiras letras, em número muito reduzido, que herdamos do período colonial, nas quais atuavam mestres régios autorizados pelo Estado, e uma rede de escolarização doméstica, centrada no ensino e na aprendizagem da leitura, da escrita e do cálculo, que atendia a um número de pessoas bem superior ao das cadeiras públicas. Os colégios, situados nas cidades maiores, e destinados às elites, recebiam alunos iniciados por essas duas modalidades de escola básica que, como Graciliano, viviam nas vilas menores das províncias.

As escolas régias ou cadeiras públicas de primeiras letras caracterizavam-se como escolas cujos professores eram reconhecidos ou nomeados pelos órgãos de governo responsáveis pela instrução e funcionavam em espaços improvisados, geralmente, na casa dos professores, os quais, algumas vezes, recebiam uma pequena ajuda para o aluguel. Os alunos e alunas dirigiam-se para a casa do mestre e lá permaneci- 
As mulheres professoras, as meninas leitoras e o menino leitor...

am por algumas horas, em geral quatro horas diárias, divididas em duas seções.

A escolarização doméstica, também chamada de particular, funcionava em espaços cedidos e organizados pelos pais - as casas de família ou as casas dos professores. O pagamento do professor era de responsabilidade do contratante individual ou de um grupo de contratantes.

É interessante destacar que, enquanto na Europa, os três séculos da época moderna são marcados pela transição de uma sociedade em que a educação se fazia por impregnação cultural para uma sociedade munida de um sistema complexo de ensino estatal, no qual a função docente, de início não especializada, exercida como ocupação secundária, vai constituindo um corpo profissional sob o controle do Estado, no Brasil, apenas no final do século XVIII e início do XIX tem início uma certa organização da instrução elementar. Esta ocorre com o envio dos mestres régios portugueses e, ao longo do século XIX, com algumas iniciativas de organização de um sistema de instrução primária e de organização e normatização do exercício da profissão docente. Até então, a educação estivera restrita à esfera privada, dependendo da importância e do sentido que as famílias conferiam à aquisição da cultura letrada.

Segundo Faria Filho (2000, p. 135-136), embora a historiografia consagrada conceba a educação primária do século XIX como um período de passagem, confinado entre a política pombalina e o florescimento da educação na era republicana, estudos recentes a respeito desse período têm demonstrado que havia, em várias províncias, uma intensa discussão acerca da necessidade de escolarização da população, sobretudo das chamadas camadas inferiores da sociedade. Ribeiro (1996, p. 35) confirma esse cenário:

No que diz respeito às leis referentes ao Ensino durante o Império, a garantia à Educação parece que permanecia apenas no discurso. $\mathrm{O}$ artigo 32, por exemplo, da Constituição Nacional de 1824, que "garantia a todos os cidadãos a educação pública", referia-se apenas aos filhos dos homens livres.

Questôes como a necessidade e a pertinência ou não da instrução de negros, índios e mulheres eram amplamente debatidas e in- 
tensa foi a atividade legislativa das Assembléias Provinciais em busca do ordenamento legal da educação escolar.

As dificuldades encontradas pelos defensores da escolarização da população livre foram de ordem econômica, uma vez que era baixíssima a capacidade de investimento das províncias, e também de ordem política e cultural. A presença do Estado não era apenas muito pequena e pulverizada, como, algumas vezes, foi considerada perniciosa no ramo da instrução.

Conforme análise de Faria Filho (2000), a implantação da educação escolar, que na modernidade se fez a partir da visibilidade e do fortalecimento das estruturas de poder estatais, representou, no Brasil do século XIX, uma disputa entre o governo do Estado e o governo da casa (p. 146). Freyre procura traçar, ao longo do século XVIII, a gênese dessas disputas, por ele sintetizada como o confronto entre o patriarcado rústico das casas-grandes e os sobrados burgueses das cidades nascentes.

O conjunto das dificuldades enfrentadas evidencia, segundo Faria Filho, que a escola não "surge no vazio deixado por outras instituiçôes":

Os defensores da escola e de sua importância no processo de civilização do povo tiveram de, lentamente, apropriar, remodelar, ou recusar tempos, espaços, conhecimentos, sensibilidades e valores próprios de tradicionais instituições de educação. Mas não apenas isso: a escola teve também de inventar, de produzir o seu lugar próprio, e o fez, também, em íntimo diálogo com outras esferas e instituições da vida social. (Faria Filho, 2000, p. 136)

Tanto nas cadeiras públicas quanto nas escolas domésticas particulares, o método de ensino era o individual.

Tal método consistia em que o professor, mesmo quando tinha vários alunos, acabava por ensinar a cada um deles individualmente. (...) O método individual caracterizava-se, pois, pelo fato de os alunos ficarem muito tempo sem o contato direto com o professor, fazendo com que a perda de tempo fosse grande e a indisciplina um problema sempre presente. (idem ibid., p. 140)

A escolha das famílias que demandavam a instrução, por uma escola ou por outra, variava de acordo com as posses e seus objetivos 
As mulheres professoras, as meninas leitoras e o menino leitor...

em relação aos filhos. Neste sentido, Graciliano relata o caso da prima Adelaide que tinha uma família rica e assim teria todas as condições para estudar em bons colégios, que seguissem a linha européia de ensino. Mas estes ficavam longe e os pais não queriam perdê-la de vista. Iriam soltá-la por este mundo, sujeita a inconveniências? Não. A pequena conservaria, perto de casa, todas as virtudes: bordaria fronhas; ligar-se-ia no altar, sem namoro, a um rapaz de juizo e fortuna, bem apessoado.

Chama atenção também o comentário de Graciliano acerca do descrédito das famílias com relação ao professor oficial e à predominância da escola particular sobre a pública.

Em Faria Filho (op. cit., p. 147), encontramos alguns indícios que podem explicar esse descrédito. Segundo esse autor, a falta de espaços próprios para as escolas tornou-se um problema administrativo, tanto no sentido dos recursos disponíveis, já que parte significativa das verbas era consumida com o pagamento do aluguel da casa de escola e do professor, e também com relação à fiscalização do próprio ensino oferecido. Como as instituições escolares eram isoladas e distantes umas das outras, acabavam não sendo fiscalizadas. Assim, os dados estatísticos eram falseados, os professores, não controlados, misturavam suas atividades de ensino a outras atividades profissionais, deixando as escolas de funcionar, em boa parte, literalmente.

Lajolo \& Zilberman (1996, p. 151), ao retomarem a história da leitura e do livro no Brasil, recolhem uma série de documentos que expressam nossa situação nos fins do século XIX e que reforçam esse panorama descrito por Faria Filho. Entre tais documentos, há um trecho transcrito de Quintino Bocaiúva, político liberal que, em artigo publicado em 1858 em um dos jornais de Petrópolis, esbraveja a respeito da situação do ensino público brasileiro:

a falta absoluta de um sistema de instrução adaptado às circunstâncias peculiares de nossa divisão administrativa; a mesquinha retribuição pecuniária dos professores e a nenhuma importância que ora se dá à profissão; a ausência de uma inspeção contínua, inteligente, vigilante e também retribuída, por isso que exigir serviços públicos gratuitamente é desejar mesmo o mau serviço.

Nos relatos de Graciliano sobre as escolas que freqüentou, são feitas várias críticas à precariedade dos espaços reservados às tarefas 
de ensino. Espaços reduzidos, desconfortáveis, via de regra compartilhados com os familiares das professoras. São também comuns as referências a outras atividades exercidas ora pelas próprias professoras, ora por seus familiares. Tarefas complementares, tais como preparar quitutes que eram vendidos aos alunos e o ensino do catecismo a eles, o que por vezes lhes rendia algum dinheiro a mais. Outras vezes, a própria professora dividia-se entre os meninos e as tarefas de costura.

Em contrapartida, enquanto o modelo escolar moderno não foi internalizado, a instrução das primeiras letras era transmitida por aqueles que dominavam alguma habilidade de leitura, escrita, cálculo etc. (Villela, 2000, p. 97-99). Era este o caso de Dona Maria, de quem Graciliano afirma que não tinha carta, ou seja, autorização ou nomeação do governo para o exercício do magistério.

A intervenção estatal quanto à formação docente efetiva-se somente com o Ato Adicional de 1834, que, transferindo para as províncias a responsabilidade pela formação de seus quadros docentes, marcará o início da criação das escolas normais provinciais e, com elas, da institucionalização do magistério. De início, essas escolas se destinaram apenas aos homens, sendo franqueadas às mulheres somente nas últimas décadas do século XIX.

A demanda por instrução apontada por Faria Filho (2000) e a ampliação da rede escolar, a partir da Lei Geral de Ensino de 1827, que propõe a homogeneização, a unificação e a hierarquização das diversificadas iniciativas docentes vigentes até então, estabelecendo a implantação, em todas as cidades, vilas e lugares mais populosos, das escolas de primeiras letras, e ainda a necessidade de mulheres para assumirem o magistério de escolas femininas, acabaram por possibilitar-lhes o acesso à profissão docente antes da regulamentação da formação pelo Estado, a exemplo do que ocorreu em outros países, como é o caso da Inglaterra.

No entanto essa possibilidade de profissionalização das mulheres enfrentou a resistência dos homens, também a exemplo da experiência européia. Segundo Perrot (1998, p. 97-98), não foi sem dificuldades que mulheres passaram a receber um salário correspondente à realização de seu trabalho: "As mulheres sempre trabalharam, mas o que colocou um problema para elas foi o exercício de trabalhos as- 
As mulheres professoras, as meninas leitoras e o menino leitor...

salariados, ofícios e profissóes praticados fora de casa. (...) As mulheres passaram por reais dificuldades para obterem o direito ao salário".

Villela (2000), em estudo sobre a profissionalização docente no Brasil, retoma a experiência das preceptoras inglesas do século XIX. Mesmo na Inglaterra moderna, industrial e não-católica, as mulheres burguesas sofreram sérias restrições a seus anseios de profissionalização, incorporando tensões no que concerne à respeitabilidade social, à moralidade sexual e à autonomia.

Os ensaístas das décadas de 30 e 40 achavam as preceptoras sexualmente vulneráveis e socialmente deslocadas. O discurso ambíguo que as apresenta como diferentes das outras mulheres e as associa àquelas que vivem à margem da sociedade deixa transparecer uma rigorosa fronteira social que separa a mulher "normal", isto é, esposa e mãe, da mulher marginal, ou seja, a louca, a prostituta e a preceptora. (Villela, 2000, p. 119)

No discurso vitoriano, ao substituir a mãe, esperava-se que a preceptora assumisse uma conduta assexuada, respeitável e pura. Contraditoriamente, por ela ser livre, solteira e desempenhar um trabalho assalariado representava uma constante ameaça aos valores e à estrutura familiar.

De 1880 em diante, qualquer preceptora que quisesse arranjar emprego teria de fornecer certificado de formação profissional especializada. A formação profissional reconhecida e a possibilidade de assumir uma escola oficial tornaram-se, entre as preceptoras inglesas, uma forma de escapar ao destino sombrio de mulheres públicas.

Assim, na Inglaterra, analisa Villela (op. cit., p. 120), a luta pela conquista desse status profissional transformou a composição dessa classe profissional durante o século XIX.

Quanto às restrições à profissionalização feminina, é interessante considerar o modo como Graciliano se refere ao marido da professora. Ele utiliza o termo "quinca", uma denominação particular, que marca, já nos inícios do século XX, a quebra do padrão patriarcal com relação ao papel dos dois sexos no casamento. Ao homem cabia abastecer a casa, a mulher e a prole, sendo vedado o trabalho fora das lides domésticas à mulher. A mulher que trabalhava e recebia um salário fugia a essas prescriçôes. 
O juízo de valor implicado na denominação - quinca - revela-se um precioso indício do significado de que se revestiu o acesso da mulher à profissão docente e de como ele foi sendo marcado discursivamente. No caso de Dona Maria, a professora de Graciliano, há uma ressalva interessante, feita pelo autor, com relação a seu Antonio Justino, o marido dela. Por Dona Maria não "ter carta" e não receber dinheiro do governo, seu Antonio Justino não era de todo quinca, de todo despersonalizado.

Pouco a pouco, as práticas mais repressivas sobre a figura da mulher-professora foram cedendo lugar à difusão de idéias que a associavam ao lar, à criança e à regeneração de uma sociedade sadia, enraizando-se nas ideologias de domesticidade e maternagem, reforçadas pelo discurso positivista e higienista.

A contrapartida feminina à ideologia da maternagem e da domesticidade, destaca Villela, foi a sua utilização como elemento de resistência: "Acatando tal discurso, as mulheres desimpediram o caminho para sua rápida inserção profissional" (2000, p. 122), ou ainda, como analisa Perrot (1998, p. 108), a entrada e consolidação da presença da mulher em certas profissóes foi um dos canais que possibilitaram a elas o ingresso no terreno da formação acadêmica de um saber especializado, que foi marcado por um saber-fazer feminino: "As escolas normais foram as primeiras universidades das mulheres".

\section{Três mulheres-professoras: Dona Maria, Dona Maria do Ó e Dona Agnelina}

Dona Maria, a professora escolhida pela família é a primeira mulher-professora a aparecer no relato.

Lavaram-me, esfregaram-me, pentearam-me, cortaram-me as unhas sujas de terra. E, com a roupa nova de fustão branco, os sapatos roxos de marroquim, o gorro de palha, folhas de almaço numa caixa, penas, lápis, uma brochura de capa amarela, sai de casa...

Conduziram-me à rua da Palha, só mais tarde notei que me achava lá, numa sala pequena. Avizinharam-me de uma senhora baixinha, gordinha, de cabelos brancos. Fileiras de alunos perdiam-se num aglomerado confuso. As minhas mãos frias não acertavam com os objetos guardados na caixa; (...) a voz da mulher gorda sussurrava docemente. 
As mulheres professoras, as meninas leitoras e o menino leitor...

O discurso que cerca a figura de Dona Maria, nos relatos de Graciliano, é todo ele marcado pela imagem de uma doçura angelical. Os gestos de Dona Maria eram brandos. Sua voz mansa. O vestido limpo. Seu cheiro agradável. Nela a cólera não se manifestava. Dona Maria, diz ele, encerrava uma alma infantil. O mundo dela era o nosso mundo, ai vivia farejando pequenos mistérios nas cartilhas. Ela cuidava do asseio dos alunos, escutava-os, guiava-os por entre as letras. Graciliano comparava-a a Nossa Senhora, nos mesmos termos que ouvira a um pregador desajeitado: "Nossa Senhora é como uma perua que abre as asas quando chove e acolhe os peruzinhos". D. Maria representava para nós essa grande ave maternal - e, ninhada heterogênea, perdiamos, na tepidez e no aconchego, os diferentes instintos de bichos nascidos de ovos diferentes.

A paz misericordiosa de Dona Maria e sua contenção - não irradiava demasiado calor. Também não esfriava - foi seguida pela presença estrepitosa de Dona Maria do Ó.

Ao se mudarem para Viçosa, o menino foi encaminhado à escola pública da professora Maria do Ó: mulata fosca, robusta em demasia, uma das criaturas mais vigorosas que já vi. Esse vigor se manifestava em repelóes, em berros, aos setenta ou oitenta alunos arrumados por todos os cantos.

Coube a Graciliano o corredor, pouco fiscalizado. Ali, entregue a si mesmo, na maior parte do tempo, era auxiliado por Dondom, mocinha pálida e misericordiosa, que lhe tomava as liçôes, corrigia-lhe a pronúncia, fazia por ele, na ardósia, as contas enigmáticas.

Na sala, vendo a mulata ou cafuza brandir a palmatória, precisaria comportar-me bem, simular atenção, molhar de saliva as páginas detestáveis. Ali [no corredor], no encolhimento e na insignificância, os livros fechados, embruteciame em leves cochilos, quase só. Desperto, bocejava, examinava o quintal estrito, que subia o morro do cemitério...

Dondom foi mais uma mulher a mediar-lhe, de modo sentimental, as arestas criadas nas relações com a mestra, de quem ele procurava escapar por entre dezenas de garotos rudes. Confrontada com a doce mestra sertaneja, clara, de belos caracóis imaculados, Dona Maria do Ó, escura, agreste, de músculos rijos e olhos raivosos de estrias amarelas, constrangida no espartilho, branqueada de pó de arroz, causava-lhe medo e repulsa. 
A última professora a que se refere é Dona Agnelina, a quem percebia quase tão ignorante quanto os alunos. Certo dia, ao procurarem em aula descobrir o significado de auréola, Dona Agnelina, que naquele instante se ocupava em coser um vestido, acabou confundindo-se e, em sua explicação, misturou auréola com ourela. Por fim, recomendou que pronunciassem a palavra de forma que se pudesse ouvir "aureóla" e não se tivessem assim mais dúvidas.

Apesar de certo desprezo que o menino nutria com relação às ignorâncias que presenciava nessa mestra que fugia às dúvidas e desconversava, ele a reconhecia como uma cativante contadora de histórias:

Essa professora atrasada possuía raro talento para narrar histórias de Trancoso. Visitava-nos, prendia-nos até meia-noite com lendas e romances, que estirava e coloria admiravelmente. Nada me ensinou, mas transmitiu-me afeição às mentiras impressas.

Três professoras. Diversas nos gestos, nas entoaçóes, na postura corporal, na relação com seus alunos e com os saberes escolares que lhes cabia ensinar. Cada uma mediou a seu modo a relação do menino com a leitura. Cada uma, a seu modo, desempenhava o papel de professora, significando o trabalho docente e compartilhando esses significados com os meninos a quem ensinava.

De Dona Maria, Graciliano aprendeu a doçura e a vencer as agruras das letras. Aprendeu um certo modelo de maternagem angelical e higiênica, que se distanciava de sua experiência doméstica. De Dona Maria do Ó, ficou-lhe a repulsa pela dissimulação. Durante as aulas, a fera metia as garras nos cabelos das crianças, mas na presença dos pais, adulava-as. Com ela pouco aprendeu sobre a escrita. Restou-lhe a revolta contra o tratamento rude e cruel que dispensava às crianças, sobretudo a sua prima Adelaide, sujeitando-a a seus mandos e desmandos. O legado de Dona Agnelina foi o gosto pelas histórias.

Essas mulheres são as precursoras das professoras do século XX. $\mathrm{O}$ que mudou fundamentalmente entre elas: o modelo de ensino, do individual para o ensino simultâneo, e o próprio estatuto da profissão, marcado pela forma escolar moderna, de serviço especializado que se desenvolve em um espaço específico e que é regido por um tempo, por normas e valores próprios da atividade docente. 
As mulheres professoras, as meninas leitoras e o menino leitor...

\section{As meninas leitoras e o menino leitor}

Se no espaço da escola formal - mesmo que precária - o menino Graciliano viveu situaçōes de constragimentos, penúrias e embaraços no aprendizado das letras, no espaço doméstico ou da rua, sua relação com a escrita foi nuançada pelas mediações configuradas pela convivência com meninas da mesma idade, como é o caso de Emília e Laura.

Dentro do círculo de suas relaçôes familiares, sua prima Emília era alguém com quem compartilhava suas investidas na leitura e também suas dúvidas e dificuldades. Tinha-a como referência, principalmente no tocante às questóes das letras.

Certa feita, após uma experiência malsucedida em que seu pai lhe propôs que lesse para ele um livro que deixara na cabeceira da cama, recorreu a ela. Para o menino, tal iniciativa tomada por seu pai com relação à leitura parecia-lhe uma segunda chance por meio da qual poderia provar não ser um maluco. Contudo, na terceira noite, sua tímida alegria e seu contentamento dissiparam-se: nunca experimentei decepção tão grande. Seu pai desistiu e, sem explicaçōes, desfez as noites de leitura. A prima representava sua derradeira oportunidade de tornar-se um leitor respeitável. Além disso, distintamente das experiências vivenciadas no ambiente escolar, Emília aparecia para ele como alguém em quem podia confiar e a quem se entregar, podendo revelar sem receio suas ignorâncias. Afinal, para ele, Emília não era deste mundo. Só se zangou comigo uma vez, no dia em que, tuberculosa, me viu beber água no copo dela. Um anjo.

Por essas razōes, decidiu-se.

Findas, porém, as manifestaçōes secretas de mágoa, refleti, achei que o mal tinha remédio e expliquei o negócio a Emilia, minha excelente prima. (...) Confessei, pois, [a ela] o meu desgosto e propus-lhe que me dirigisse a leitura. (...). Assim, era necessário que a minha priminha lesse comigo o romance e me auxiliasse na decifração dele.

Nas leituras que compartilhava com Emília, surpreendeu-se redescobrindo as histórias, interessando-se pelas personagens, compreendendo certas narrativas. Passado algum tempo, essa Águeda me serviu muito. (Ana, achei que ficou meio solto. Que Águeda é essa, perguntar-se-á o leitor!!!!) 
As mediações de Emília não pararam por aí. A menina, para surpresa de seu primo, desafiou-o com uma proposta: por que não me arriscava a tentar a leitura sozinho? Graciliano procurou, a todo custo, convencê-la de sua limitação e da impossibilidade de realizar tal ousadia. Porém sua prima não desistiu da empreitada e, determinada a mudar o rumo do menino, insistiu.

Emilia combateu a minh a convicção, falou-me dos astrônomos, indivíduos que liam no céu, percebiam tudo quanto há no céu. Não no céu onde moram Deus Nosso Senhor e a Virgem Maria. Esse ninguém tinha visto. Mas o outro, o que fica por baixo, o do Sol, da Lua e das estrelas, os astrônomos conheciam perfeitamente. Ora, se eles enxergavam coisas tão distantes, por que não conseguiria eu adivinhar a página aberta diante dos meus olhos? Não distinguiria as letras? Não sabia reuni-las e formar palavras?

Matutei na lembrança de Emília. Eu, os astrônomos, que doidice! Ler as coisas do céu, quem havia de supor?

E tomei coragem, fui esconder-me no quintal, com os lobos, o homem, a mulher, os pequenos, a tempestade na floresta, a cabana do lenhador. Reli as folhas já percorridas. Eas partes que se esclareciam derramavam escassa luz sobre os pontos obscuros. Personagens diminutas cresciam, vagarosamente me penetravam a inteligência espessa. Vagarosamente.

Assim, graças à intermediação de Emília, o universo das letras parecia-lhe outro. Não mais tingido apenas pela tinta preta, mas ganhando cor e um aspecto mais alegre. Um novo mundo descortinou-se para o menino. A escrita agora não se revestia apenas do caráter rígido, coberto de punições e castigos, experimentado outrora. A partir dessa outra relação com a escrita, o menino podia se recolher em segredo com os livros, junto às narrativas e às personagens, sem as interferências e cobranças intempestivas vivenciadas na realidade escolar.

$\mathrm{Na}$ ambiência do convívio familiar, procurava freqüentemente por sua prima em suas novas investidas para ampliar o restrito repertório de leituras ao qual tinha acesso. Foi com ela que compartilhou a iniciativa de procurar Jerônimo Barreto, que possuía a maior biblioteca da cidade, para pedir-lhe o empréstimo de seus livros. Junto dela também dividia suas leituras, mesmo que fosse para discordarem em seus pontos de vista, como foi o caso do folheto amarelo "O menino da mata e seu cão Piloto", em que veio-me a idéia de me rebelar contra Emilia. A escrita, para o menino, tinha agora outro estatuto. Se anteriormente era motivo de pavor e calafrios, passou a ser razão da maior 
As mulheres professoras, as meninas leitoras e o menino leitor...

aproximação de sua prima, de seus encontros em meio à tessitura de relaçôes familiares.

Ao mesmo tempo em que construía uma relação de cumplicidade com Emília, mediada pelos enredos que as letras impressas contavam nas páginas brancas ou amareladas, o menino Graciliano foi desenvolvendo um senso próprio, desvencilhando-se assim até da ascendência que a prima tinha sobre ele. $\mathrm{O}$ caso do folheto amarelo expressa a autonomia que estava sendo pouco a pouco construída. Apesar de Emília afirmar-lhe ser aquela história proibida, pois devia ser coisa do diabo, ele não quis aceitar. $\mathrm{O}$ leitor já não se submetia às interdições postas aos textos. Morais (1998, p. 75), ao acompanhar as leituras femininas, observa tal comportamento de insubordinação das mulheres leitoras:

Quer seja em termos da sua compreensão, quer seja pela autoridade que o encomenda ou permite sua publicação, quer seja pela própria organização numa biblioteca. Apesar disso, o livro não consegue instaurar uma ordem no leitor. O leitor é livre para se inscrever no texto e pôr também a sua marca, modificando-o e modificando-se.

Laura, sua colega em um exame da escola, foi outra menina que mediou sua relação com a escrita, não de modo intencional e explícito como aconteceu com Emília. Sua intervenção foi de outra natureza, levando-o a experimentar sentimentos até então desconhecidos. Primeiro veio a admiração:

Foi então que vi Laura, num exame. Jovino Xavier fez-lhe perguntas comuns; notando-lhe a fortaleza, puxou por ela e declarou a análise sem jaça. Ouviu os discursos, recebeu os agradecimentos da professora e elogiou em demasia a inteligência e o progresso de Laura. Concordei. Invadiu-me súbita admiração, que em breve se mudou numa espécie de culto.

A escrita então se insurge e se insinua como companheira da paixão que se instala, chegando a atormentá-lo. As narrativas passam a mediar seus sonhos. À noite, procurando conciliar-se com o sono, Laura voltava-lhe à cabeça, começava a habitar os romances que naquela altura de sua meninice lia desenfreadamente, convertendo-se nas personagens. A leitura passou, desse modo, a assombrá-lo:

Sensaçôes desencontradas, assaltavam-me: ardia-me a cabeça, os dedos tiritavam, frios como gelo. Impossivel suportar o contato dos lençóis. Erguia-me 
sufocado, ia balançar-me devagar na rede. Já não acendia o candeeiro. Temia privar-me do fantasma, recuperar a calma. E a leitura me enfastiava: um mês a arrastar-me no "Sonho de Zola", sem nenhum desejo de chegar ao fim, interpretando a narrativa a meu jeito. A bordadeira de paramentos, que se confundia com as santas de Jacques de Voragine, convertia-se em Laura, e eu a contemplava, personagem de romance também, num andaime, junto ao muro de uma catedral.

Laura, sem ter a mínima noção de sua importância, acabou proporcionando ao menino apaixonado um mergulho ainda mais profundo no mundo governado pelas letras. A escrita invadiu sua vida, em uma viagem sem retorno, ocupando lugar privilegiado nos seus poucos domínios até então conquistados. Com as letras, passou até a lutar, brigando em meio às narrativas pela conservação pura e angelical de sua amada, procurando com isso negar as influências indecentes do movimento naturalista, preservando assim sua beleza virginal.

Embrulhara com ódio "O Cortiço" em muitas dobras de papel grosso, amarrara-o em muitas voltas de barbante forte, escondera-o por detrás dos outros volumes, na prateleira inferior da estante. Apontavam no romance passagens cruas - e a contaminação me horrorizava. Do naturalismo apenas conservava "O Sonho". (...). Certo não existia alma em Laura; indignava-me, porém, reduzi-la a um organismo sujeito às exigências comuns.

Embora Emília e Laura tenham ocupado papéis diferenciados nas relações compartilhadas com o menino Graciliano, cada uma, a sua maneira, marcou os significados que ele passou a atribuir ao universo da escrita. As duas meninas proporcionaram-lhe uma imersão no mundo das letras muito diferente e distante daquele apresentado pelas suas primeiras professoras, no ambiente de ensino cercado pela formalidade e pela atmosfera ríspida das normas. Também se tornavam distintas em função de lhe mostrarem um outro modelo de mulher que se formava: não mais restrita às instâncias e aos interesses domésticos e menos ignorante no que concernia aos conhecimentos gerais, de domínio público.

Sobre essa nova mulher que se formava e essa nova mentalidade, Ribeiro (1996, p. 147), ao relatar mudanças ocorridas no sudeste brasileiro um pouco antes do período citado com relação a Pernambuco e Alagoas, traz algumas contribuiçóes para compreendermos essa mudança que se delineava no universo feminino: 
As mulheres professoras, as meninas leitoras e o menino leitor...

Se, antes, o ideal doméstico imputava às mulheres sua condição de submissão, nesse período (final do Brasil Monárquico) elas tinham a necessidade de freqüentar os espaços públicos. Em não existindo, elas os criavam (...). A mentalidade dessas jovens, parece-me, era cercada de muita criatividade e bom humor.

Se é verdade que às mulheres se restringiam as práticas de leitura e escrita, também parece verdade que tal restrição não as impedia de construir, de modos peculiares, seus repertórios, diferentes daquele almejado pela racionalidade da sociedade agrária que se encontrava em declínio.

Os contatos diversos que o menino Graciliano teve com a escrita, intermediados pelas várias mulheres e meninas que cruzaram seu caminho no período da infância, indiciam como as práticas socioculturais que estavam em pleno transcurso da história foram sendo apropriadas e re-significadas pelas gerações de mulheres e homens, meninos e meninas que viviam no agreste urbano-rural brasileiro do começo do século XX.

\section{Recebido em agosto de 2003 e aprovado em abril de 2004.}

\section{Notas}

1. Todas as citações em itálico irão referir-se a trechos transcritos do livro Infância, de Graciliano Ramos.

2. O estudo de Park (1999) mostra como a prática de leitura de almanaques era e ainda é forte no Brasil, principalmente nas regiões interioranas e zonas rurais, onde o acesso a materiais impressos não era fácil e a circulação de livros era restrita, como a região em que Graciliano viveu. Além disso, diversos trechos citados pelo autor a respeito do conteúdo dos textos de sua mãe têm relação direta com os temas tratados naquela época por vários almanaques que circulavam no Brasil, tais como datas comemorativas, superstições e crenças, normas de conduta, festas religiosas, datas de santos etc. Para se ter uma idéia, um deles, o "Pharol da Medicina", teve tiragem de 50 mil exemplares entre 1897 e 1905. Ainda segundo a autora, um outro estudioso brasileiro, Souto Maior, "nos mostra que, em seu estado, Pernambuco, este tipo de literatura representava apenas a ponta de um iceberg" (Park, 1999, p. 71).

3. Park (1999), ao descrever diversos assuntos tratados pelos almanaques, menciona diversas matérias sobre o aparecimento do cometa Halley no início do século XX, tema comentado neste episódio: "O fim do mundo" e que tanto causou aflição à mãe do menino Graciliano. A autora comenta a respeito da capa de um dos números do almanaque Iza: "A escolha do nome, Cometa Halley, um corpo celeste, reflete o universo dos almanaques ligado ao mundo dos astros" (op. cit., p. 80). 
Referências bibliográficas

FARIA FILHO, L.M. Instrução elementar no século XIX. In: Lopes, E. M.T.; Faria Filho, L.M.; VeIgA, C.G. (Org.). 500 anos de educação no Brasil. Belo Horizonte: Autêntica, 2000.

FREYRE, G. Sobrados e mucambos: decadência do patriarcado rural no Brasil. São Paulo: Nacional, 1936.

LAJOLO, M. Literatura: leitores e leitura. São Paulo: Moderna, 2001. LAJOLO, M.; ZILBERMAN, R. A formação da leitura no Brasil. São Paulo: Ática, 1996.

LE GOFF, J. História. In: Enciclopedia Einaudi. Lisboa: Imprensa Nacional, 1984. v. 1

MORAIS, M.A.C. de. A leitura de romances no século XIX. Cadernos Cedes, Campinas, n. 45, 1998.

PARK, M. Histórias e leituras de almanaques no Brasil. Campinas: Mercado de Letras, 1999.

PERROT, M. Mulheres públicas. São Paulo: UneSP, 1998.

RAMOS, G. Infância. 13. ed. Rio de Janeiro: Record, 1986.

RIBEIRO, A. A educação feminina durante o século XIX: o Colégio Florence de Campinas 1863-1889. Campinas: Centro de Memória da UNICAMP, 1996.

RIBEIRO, A. Mulheres educadas na colônia. In: LoPES, E.M.T.; FarIA Filho, L.M.; VeigA, C.G. (Org.). 500 anos de educação no Brasil. Belo Horizonte: Autêntica, 2000.

VIDAL, D. De Heródoto ao gravador: histórias da história oral. Resgate, Campinas, n. 1, 1990.

VILLELA, H.O.S. O mestre-escola e a professora. In: LOPES, E.M.T.; FARIA Filho, L.M.; Veiga, C.G. (Org.). 500 anos de educação no Brasil. Belo Horizonte: Autêntica, 2000. 